\title{
REVIEW
}

\section{Regulatory T-cell vaccination independent of auto-antigen}

\author{
David W Pascual ${ }^{1}$, Xinghong Yang ${ }^{1}$, Kathryn Holderness ${ }^{2}$, SangMu Jun ${ }^{1}$, Massimo Maddaloni ${ }^{1}$ \\ and Irina Kochetkova ${ }^{2}$
}

To date, efforts to treat autoimmune diseases have primarily focused on the disease symptoms rather than on the cause of the disease. In large part, this is attributed to not knowing the responsible auto-antigens (auto-Ags) for driving the self-reactivity coupled with the poor success of treating autoimmune diseases using oral tolerance methods. Nonetheless, if tolerogenic approaches or methods that stimulate regulatory $\mathrm{T}\left(\mathrm{T}_{\text {reg }}\right)$ cells can be devised, these could subdue autoimmune diseases. To forward such efforts, our approach with colonization factor antigen I (CFA/I) fimbriae is to establish bystander immunity to ultimately drive the development of auto-Ag-specific $\mathrm{T}_{\text {reg }}$ cells. Using an attenuated Salmonella vaccine expressing CFA/I fimbriae, fimbriae-specific $T_{\text {reg }}$ cells were induced without compromising the vaccine's capacity to protect against travelers' diarrhea or salmonellosis. By adapting the vaccine's anti-inflammatory properties, it was found that it could also dampen experimental inflammatory diseases resembling multiple sclerosis (MS) and rheumatoid arthritis. Because of this bystander effect, disease-specific $T_{\text {reg }}$ cells are eventually induced to resolve disease. Interestingly, this same vaccine could elicit the required $\mathrm{T}_{\text {reg }}$ cell subset for each disease. For MS-like disease, conventional $C D 25+\mathrm{T}_{\text {reg }}$ cells are stimulated, but for arthritis CD39 ${ }^{+} \mathrm{T}_{\text {reg }}$ cells are induced instead. This review article will examine the potential of treating autoimmune diseases without having previous knowledge of the auto-Ag using an innocuous antigen to stimulate $\mathrm{T}_{\text {reg }}$ cells via the production of transforming growth factor- $\beta$ and interleukin-10.

Experimental \& Molecular Medicine (2014) 46, e82; doi:10.1038/emm.2014.4; published online 14 March 2014

Keywords: autoimmunity; bacteria; fimbriae; mucosal immunity; regulatory T cells; vaccine

\section{COLONIZATION FACTOR ANTIGEN I (CFA/I) FIMBRIAE AND ENTEROTOXIGENIC ESCHERICHIA COLI (ETEC)}

ETEC, the causative agent of travelers' diarrhea, is the most common bacterial diarrheal disease of children in Latin America, Asia and Africa, ${ }^{1}$ and it is contracted upon ingestion of contaminated food or water. It is estimated that this disease is responsible for 400 million cases annually resulting in 300000 deaths of preschool children., ${ }^{2,3}$ E. coli becomes enterotoxigenic upon acquisition of a plasmid or plasmids containing the heat-stable enterotoxin ${ }^{4}$ or the cholera-like exotoxin, which is commonly termed the heatlabile enterotoxin (LT). ${ }^{5,6}$ Both toxins are responsible for inducing fluid loss and electrolyte imbalance in the host. Facilitating infection and subsequent colonization, ETEC also acquires a plasmid encoding for the pili or fimbriae referred to as colonization factor antigens (CFAs), which mediate the colonization of E. coli in the gastrointestinal tract. The CFA pili are a heterogenous group of fimbrial adhesins responsible for adherence to small intestinal epithelial cells via their fimbriae or long, hairlike projections extending from the bacterial cell surface to epithelial mannose-containing glycoproteins. ${ }^{7}$ This adherence is generally host-specific for intestinal epithelium. ${ }^{8}$ While a specific natural receptor for CFA/I fimbriae has yet to be identified in the small intestine, some studies suggest that in eukaryotes a sialylated glycoprotein is the receptor, ${ }^{9,10}$ although others suggest that epithelial mannose-containing glycoproteins and/or glycosphingolipids may also serve as receptors. ${ }^{11,12}$ The low incidence rates in adults from ETECendemic regions have correlated with the presence of anti-LT and anti-CFA antibodies (Abs), suggesting that acquired immunity to these virulence factors are protective. ${ }^{13}$ Epidemiological studies show that children aged $<3$ years from these endemic regions are susceptible to multiple ETEC infections, which may provide for broad-spectrum immunity

\footnotetext{
${ }^{1}$ Department of Infectious Diseases and Pathology, College of Veterinary Medicine, University of Florida, Gainesville, FL, USA and ${ }^{2}$ Department of Immunology and Infectious Diseases, Montana State University, Bozeman, MT, USA

Correspondence: Dr DW Pascual, Department of Infectious Diseases and Pathology, College of Veterinary Medicine, University of Florida, P.O. Box 110880, Gainesville, FL 32611, USA.

E-mail: pascuald@ufl.edu
}

Received 22 November 2013; accepted 6 December 2013 
later in life, ${ }^{14,15}$ while adult travelers to these endemic regions are unprotected and remain susceptible to infection. $2,3,16,17$

CFA/I fimbriae are an archetype of class 5 fimbriae characterized by a common four-gene operon. ${ }^{18,19}$ For CFA/ $\mathrm{I}$, this is $c f a A B C E .^{11}$ This operon contains four genes in the following order: periplasmic chaperone $c f a A$, major fimbrial subunit $c f a B$, outer membrane usher protein $c f a C$, and minor fimbrial subunit $c f a E .^{11,18} \mathrm{CfaA}$ functions as a chaperone to facilitate proper folding of other components of the operon to the outer membrane, while CfaC 'ushers' the structural fimbrial proteins and orchestrates their assembly at the cell surface. The extracellular portion of CFA/I fimbriae comprises two proteins, $\mathrm{CfaB}$ and $\mathrm{CfaE}$, and assembles with a single copy of CfaE followed by multiple copies of CfaB. ${ }^{19,20}$ In fact, $\mathrm{CfaB}$ is the major pilin subunit, and it is present as approximately 1000 copies on the cell surface per single copy of the minor subunit, CfaE. ${ }^{19}$

\section{CFA/I FIMBRIAE ARE HIGHLY IMMUNOGENIC AND CONFER PROTECTION AGAINST ETEC}

Attempts to successfully vaccinate against ETEC have met with varied success. Oral vaccination of human volunteers with CFA/I or CFA/II fimbriae failed to induce significant serum immunoglobulin G (IgG) or secretory IgA (SIgA) Abs. ${ }^{21}$ As a result of poor anti-fimbriae $\mathrm{Ab}$ titers, ${ }^{22,23}$ the human volunteers were not protected against virulent ETEC. ${ }^{22}$ Despite neutralization of their stomach acidity, ${ }^{23}$ poor SIgA anti-CFA Ab responses were obtained in these volunteers. Subsequent work showed that gastric proteases altered the CFA fimbriae antigenicity even at a neutral $\mathrm{pH} .{ }^{24}$ Overcoming the deleterious effects of the gastrointestinal tract, oral vaccination of rabbits with microencapsulated CFA/I fimbriae still failed to induce serum and fecal IgA anti-CFA/I Abs. ${ }^{21}$ Although in a separate study, microencapsulated CFA/II fimbriae when directly intubated into the rabbit duodenum revealed that CFA/II fimbriae-specific Ab-forming cell responses could be induced in the Peyer's patches and spleens. ${ }^{25}$ Once elicited, Abs to these fimbriae do protect against ETEC infection. ${ }^{26,27}$ An effective vaccine for ETEC still remains elusive, but promising results have been obtained from recent human trials using heat-killed ETEC plus recombinant LT-B/CT-B, ${ }^{1}$ suggesting the fimbriae are optimally immunogenic when associated with the bacilli.

Attenuated, live Salmonella vectors have been extensively used as a means to vaccinate against salmonellosis ${ }^{28-31}$ and heterologous diseases. ${ }^{32}$ Such attenuated Salmonella strains have been shown to be effective in delivering heterologous antigens (Ags) because of their ability to stimulate both mucosal and systemic immune compartments ${ }^{29,33}$ most likely via infection of Peyer's patches and followed by subsequent spread into systemic immune compartment. ${ }^{31,34}$ Therefore, an ETEC vaccine adapted as an attenuated, balanced-lethal $\triangle a r o A$ Lasd S. Typhimurium vaccine carrying an $a s d^{+}$plasmid encoding the CFA/I operon. ${ }^{35}$ The expression of this fimbriae appears similar ${ }^{36,37}$ to wild-type ETEC with long, hairlike projections extending from the bacterial cell surface. ${ }^{23}$ Upon oral immunization, Salmonella-CFA/I was quite adept in stimulating elevated mucosal IgA and serum IgG Abs to the fimbriae. ${ }^{35,38}$ Interestingly, the CFA/I fimbriae stimulated a biphasic $\mathrm{T}$ helper (Th) cell response with a rapid induction of Th2 cells within the first week of vaccination followed by a progressively increasing Th1 cell response to eliminate the salmonellae. ${ }^{38}$ This was corroborated by the stimulation of elevated serum IgG1 Abs relative to IgG2a shortly after vaccination. ${ }^{38}$ This is atypical to immune responses to Salmonella vaccines, which generally are Th1 cell-dependent promoting serum IgG2a Abs. ${ }^{39-48}$ Despite this obvious difference in Th cell profiles, the expression of CFA/I fimbriae did not alter its capacity to protect against wildtype Salmonella challenge. ${ }^{49}$ Given the highly proinflammatory nature of Salmonella, ${ }^{39,42,50}$ subsequent analysis assessed whether the CFA/I fimbriae interfered with the normal recognition of the bacilli. Upon infection of RAW264.7 or thioglycolate-induced macrophages with low infection ratios of Salmonella-CFA/I, minimal-to-no interleukin (IL)-1 $\alpha$, IL-1 $\beta$, IL-6 and tumor necrosis factor (TNF)- $\alpha$ production was observed in contrast to its isogenic Salmonella vector strain eliciting all of these proinflammatory cytokines with as few as one bacterium/80 macrophages. ${ }^{51}$ To ascertain why such a profound disparity in proinflammatory cytokine production, subsequent analysis could not find any differences in Salmonella colonization or increased susceptibility to macrophage cell death nor were there increases in anti-inflammatory IL-10 or IL-12p40 cytokines. ${ }^{51}$ Although the mechanism for the stealth-like qualities of Salmonella-CFA/I was not discerned, a possible explanation for these observations may be that the CFA/I fimbriae thwart innate immune responses by hindering detection by individual or a combination of pathogenrecognition receptors, including Toll-like receptor 4 (TLR4), TLR5, CD14, MD2 and lipopolysaccharide-binding protein, ${ }^{52}$ to indicate Salmonella's presence. Hence, we hypothesized that the Salmonella-CFA/I may be an anti-inflammatory vaccine.

\section{SALMONELLA-CFA/I AS AN ANTI-INFLAMMATORY VACCINE FOR AN ANIMAL MODEL OF MULTIPLE SCLEROSIS (MS)}

The surprising results from the macrophage infection studies indicated that Salmonella-CFA/I was not eliciting the proinflammatory arm of immunity. Moreover, the stimulation of Th2 cells and associated anti-inflammatory cytokines suggests that this vaccine may also be therapeutic in treating autoimmune diseases, such as MS or arthritis. MS is an inflammatory demyelinating disease of the central nervous system (CNS) with destruction of white matter by autoreactive $\mathrm{T}$ cells. $^{53-56}$ This neurodegenerative disease affects as many as 400000 people in United States and $>2$ million people worldwide. ${ }^{57}$ The frequency of MS is thought to be age and gender dependent, as it most frequently affects young and middle-aged adults and occurs twice as often in females as in males. ${ }^{54,57,58}$ Although not considered fatal, MS can progress into considerable neurological disability, impacting the quality of life, and resulting in a shortened lifespan. ${ }^{59}$ 
Experimental autoimmune encephalomyelitis (EAE) is one of the best and most frequently studied rodent model that mimics the neuropathology and clinical disease of MS. ${ }^{60-65}$ EAE manifests as an ascending disease in the spinal cord where initial symptoms begin as a limp or paralyzed tail, followed by rear leg paralysis that can eventually progress into forearm paralysis. ${ }^{66}$ It is induced upon immunization with restricted CNS peptides, such as myelin oligodendrocyte glycoprotein, ${ }^{67}$ myelin basic protein ${ }^{67}$ or proteolipid protein (PLP), ${ }^{68}$ into susceptible mice. This injection results in the activation of myelin-specific $\mathrm{CD}^{+} \mathrm{T}$ cells in naive animals where in the CNS inflammatory cells are recruited that secrete interferon (IFN)- $\gamma$, TNF- $\alpha$ and IL-1, resulting in perpetuation of inflammation along with tissue damage, including axonal damage, demyelination and perivascular inflammatory lesions. ${ }^{69}$ Due to demyelination, new epitopes become exposed, and exposure of these neoAgs acts as an immunization process, thereby causing further epitope spreading. ${ }^{62,70-72}$ Studies have shown that the proinflammatory-promoting cytokine, IL-23, is primarily responsible for encephalitogenic T-cell development in EAE. ${ }^{73-75} \mathrm{IL}-17$ is the principal mediator of the inflammation observed in $\operatorname{EAE}^{76-79}$ and in large part induced by IL-23. ${ }^{73-76}$ IL-17 is cross-regulated by both IL-4 and IFN- $\gamma \cdot{ }^{76}$ Neutralization of IL-17 has been shown to be protective, ${ }^{76-79}$ and protection can also be mediated via regulatory $\mathrm{T}\left(\mathrm{T}_{\mathrm{reg}}\right)$ cells. ${ }^{80-83}$ The proinflammatory cytokines IFN- $\gamma^{84-87}$ and TNF- $\alpha^{73,74,82,85,88}$ can also impact disease primarily via Th1 cells. Protection to EAE correlates with $\mathrm{Th} 2 / \mathrm{T}_{\text {reg }}$ cell dependence as IL-4, ${ }^{80,89-91}$ IL-1 $10^{71,72,85,92-94}$ and transforming growth factor (TGF)- $\beta^{80,82,89,95-97}$ can reverse or prevent EAE. IL-27 has also been shown to be important for induction of protective $\mathrm{T}_{\text {reg }}$ cells. ${ }^{98-100}$

As for many autoimmune diseases, patients have lost the capacity to be tolerized to self, and consequently, the patient begins to mount an immune response to self much like recognition of foreign Ags. This T-cell dysfunction exhibited in these patients results in chronic activation of inflammatory Th1 and Th17 cells. ${ }^{101,102}$ Often the course of treatment involves anti-inflammatory drugs and does not address the cause of the disease. Certainly, an approach that has had experimental success is the induction of tolerance. Tolerance is the inability to recognize self or to defined Ags (reviewed in Faria and Weiner, ${ }^{103}$ Mueller ${ }^{104}$ and Bilate and Lafaille ${ }^{105}$ ) and past efforts to induce tolerance in humans by delivering Ags have proven successful for treating allergies. ${ }^{106-108}$ The major obstacle in human tolerance is in part attributed to the requirement for large doses of $\mathrm{Ag}$ or repeated administrations of therapeutics. ${ }^{106}$ Although feeding autoAgs is effective in treating experimental autoimmune diseases, when applied to patients, oral feeding with autoAgs has been deemed unsuccessful. ${ }^{109,110}$

As noted, the Salmonella-CFA/I vaccine elicited Th2-type responses to the fimbriae ${ }^{38}$ much like an effect of soluble Ag with adjuvant. ${ }^{12}$ The observed Th2 cell bias was directed to the fimbriae but not as much as to the Salmonella vector, which still retained the capacity to stimulate Th1-type responses against Salmonella Ags. ${ }^{111}$ With this backdrop, subsequent studies began to analyze the potential of Salmonella-CFA/I to augment disease, first with PLP $_{139-151}$-induced EAE. ${ }^{12}$ As Salmonella-CFA/I elicits a biphasic Th cell response, groups of mice were orally vaccinated 1 week or 4 weeks before EAE challenge to coincide with a more Th2 cell- or Th1 cell-prone environment, respectively. In either case, Salmonella-CFA/I still conferred protection recovering completely from disease unlike those mice vaccinated with an isogenic Salmonella vaccine lacking CFA/I fimbriae or those mice treated with phosphatebuffered saline (PBS). ${ }^{12}$ However, mice vaccinated with the isogenic Salmonella vector did show reduced disease relative to PBS-treated mice but still bore greater disease than those mice vaccinated with Salmonella-CFA/I. In addition to the clinical scores, increased disease pathology of the CNS was evident from the enhanced demyelination and inflammatory cell infiltration relative to Salmonella-CFA/I-vaccinated mice. This protection was supported by increased production of IL-4, IL-10 and IL-13 and diminished production of IFN- $\gamma$ by PLP $_{139-151^{-}}$or CFA/I fimbriae-restimulated CD4 ${ }^{+} \mathrm{T}$ cells. ${ }^{12}$ In contrast, $\mathrm{CD}^{+} \mathrm{T}$ cells isolated from unprotected or Salmonella vector-immunized mice ${ }^{112}$ displayed elevated IFN- $\gamma$ and minimal-to-no Th2-type cytokines. Thus, Salmonella-CFA/I was successful in reducing EAE severity in a bystander fashion when administered before disease induction.

Although these prophylactic results were clearly promising, often with human autoimmune diseases, it is unknown which patients will develop disease and at what time point. Therefore, to address the therapeutic potential of oral Salmonella-CFA/I, additional studies were conducted to determine whether it could impact ongoing disease. ${ }^{68}$ Adapting the same PLP ${ }_{139-151}$ challenge model, mice were subjected to intervention with Salmonella-CFA/I, Salmonella vector or PBS 6 days post-EAE induction. As per the prophylactic studies, both the Salmonella-CFA/I and Salmonella vector were able to subdue disease to different degrees, but only Salmonella-CFA/I was able to inhibit CNS inflammation unlike the Salmonella vector-treated mice, which showed extensive neutrophil, macrophage and T-cell infiltration into the CNS.68 Protection to EAE by Salmonella-CFA/I was attributed to the stimulation of anti-inflammatory cytokines, IL-4, IL-10 and IL-13 with concomitant reductions in IFN- $\gamma$ and IL-17. ${ }^{68}$

Because of the observed anti-inflammatory cytokines, we queried whether these were generated by $\mathrm{T}_{\text {reg }}$ cells, possibly induced by Salmonella-CFA/I. $\mathrm{T}_{\text {reg }}$ cells were originally delineated in thymectomized neonatal mice that showed increased manifestations of autoimmune disorders. ${ }^{13,114}$ As a result, $\mathrm{T}_{\text {reg }}$ cells have been shown to maintain peripheral tolerance and are responsible for protection against a variety of autoimmune diseases, including colitis, ${ }^{115}$ arthritis ${ }^{116}$ and EAE. ${ }^{81,83,105,117}$

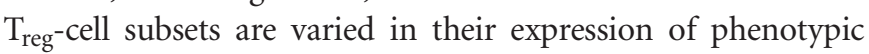
markers, but natural $\mathrm{T}_{\text {reg }}$ cells are identified by the expression of IL-2 receptor $\alpha$-chain. ${ }^{113}$ These are also transcriptionally regulated by forkhead box transcription factor (Foxp3), ${ }^{117-120}$ 
and when Foxp3 function is ablated, $\mathrm{CD} 4{ }^{+} \mathrm{CD} 25^{+} \mathrm{T}_{\text {reg }}$ cells are abrogated producing a wasting disease and inflammatory bowel disease in mice. ${ }^{118,119}$ Co-inhibitory molecules, activation-induced cytotoxic $\mathrm{T}$ lymphocyte associated protein-4 and glucocorticoid-induced TNF receptor may also be expressed and contribute in mediating $\mathrm{T}_{\text {eff }}$ cell suppression. ${ }^{121,122}$ In lieu of the phenotypic markers, earlier studies relied on functional characterization of these $T_{\text {reg }}$ cells, and these were distinguished by the cell surface expression or secretion of TGF- $\beta^{120,123,124}$ referred to as Th3 cells $s^{125}$ or production of IL-10 referred to as $\mathrm{T}_{\text {regulatory }} 1$ cells. ${ }^{126,127}$ TGF- $\beta$ production by $\mathrm{CD} 25^{+} \mathrm{CD} 4{ }^{+} \mathrm{T}_{\text {reg }}$ cells has been shown to be responsible for recovery from EAE, ${ }^{68,89,95-97,123,128}$ and the presence of TGF- $\beta$ has been shown to be necessary for conversion of $\mathrm{CD} 4{ }^{+} \mathrm{CD} 25^{-} \mathrm{T}$ cells into $\mathrm{CD} 4{ }^{+} \mathrm{CD} 25^{+}$ FoxP3 ${ }^{+} \mathrm{T}_{\text {reg }}$ cells. ${ }^{120,121,124,129}$ More recently, IL-35, a member of the IL-12 family and produced by $\mathrm{T}_{\text {reg }}$ cells, was found to have inhibitory activity capable of potently suppressing arthritis, ${ }^{130,131}$ colitis $^{132,133}$ and EAE. ${ }^{134}$ IL-35 can mediate its effects via the stimulation of IL-10. ${ }^{130,131,135}$

To examine the possible role for induction of $\mathrm{T}_{\text {reg }}$ cells by Salmonella-CFA/I, a kinetic analysis was done. It was discovered that both the Salmonella vector and Salmonella-CFA/I could stimulate the induction of $\mathrm{CD} 25^{+} \mathrm{CD}^{+} \mathrm{T}$ cells, but the percentage of Foxp $3^{+} \mathrm{T}_{\text {reg }}$ cells was particularly augmented in mice treated with Salmonella-CFA/I. ${ }^{68}$ To assess their relative contribution, in vivo $\mathrm{CD} 25$ neutralization was performed resulting in the diminution of Salmonella-CFA/I's protective response demonstrating the importance of these $\mathrm{T}_{\text {reg }}$ cells to abate autoimmune disease. ${ }^{68}$ To assess their relative potency, adoptive transfer of $\mathrm{T}_{\text {reg }}$ cells from each of the treatment groups (Salmonella-CFA/I, Salmonella vector and naive) was tested. ${ }^{68} \mathrm{~T}_{\text {reg }}$ cells derived from mice vaccinated with Salmonella-CFA/I showed the greatest potency in $\mathrm{PLP}_{139-151^{-}}$ challenged mice exhibiting nearly complete protection. Conversely, although $\mathrm{T}_{\text {reg }}$ cells obtained from Salmonella vector-vaccinated mice did confer protection, some disease was still evident that was subsequently protracted. Recipients adoptively transferred with naive $\mathrm{T}_{\text {reg }}$ cells only showed a delayed onset of disease, and all mice developed EAE. Interestingly, partial protection could be achieved with $\mathrm{CD} 25^{-} \mathrm{CD} 4^{+} \mathrm{T}$ cells adoptively transferred from Salmonella-CFA/I-vaccinated mice unlike those same cells from Salmonella vector-immunized mice that were unable to confer protection. The adoptively transferred $\mathrm{T}_{\text {reg }}$ cells from Salmonella-CFA/I-vaccinated mice produced both TGF- $\beta$ and IL-10, but the majority of the IL-10 was derived from $\mathrm{CD} 25^{-} \mathrm{CD} 4{ }^{+} \mathrm{T}$ cells. Moreover, these $\mathrm{CD} 25^{-} \mathrm{CD} 4{ }^{+} \mathrm{T}$ cells produced IL-4 and IL-13, suggesting these are potentially Th2 cells. $\mathrm{T}_{\text {reg }}$ cells from Salmonella vector-vaccinated mice produced little TGF- $\beta$ and IL- 10 , and their $\mathrm{CD} 25^{-} \mathrm{CD} 4{ }^{+} \mathrm{T}$ cells did not produce IL-4, IL-10 or IL-13, which accounts for the lesser potency in reducing EAE. ${ }^{68}$ As TGF- $\beta 1^{-1-}$ mice succumb to death in utero and those surviving succumb early in life, ${ }^{136}$ additional adoptive transfer studies were performed to test the dependence on TGF- $\beta$ for protection to EAE. ${ }^{137}$
Upon adoptive transfer of $\mathrm{T}_{\text {reg }}$ or $\mathrm{CD} 25^{-} \mathrm{CD} 4^{+} \mathrm{T}$ cells from Salmonella-CFA/I-vaccinated mice, recipients induced with EAE were neutralized of their TGF- $\beta$ using a monoclonal $\mathrm{Ab}$ $(\mathrm{mAb})$, and this abrogated much of the protective effect by Salmonella-CFA/I's $\mathrm{T}_{\mathrm{reg}}$ cells. Complete abrogation was observed upon treating recipients with Salmonella-CFA/I's $\mathrm{CD} 25^{-} \mathrm{CD} 4{ }^{+} \mathrm{T}$ cells. ${ }^{137}$ As with this latter finding, TGF- $\beta$ neutralization resulted in the complete loss of any partial protection conferred by Salmonella vector $\mathrm{T}_{\mathrm{reg}}$ cells, and no protection was evident in recipients given $\mathrm{CD} 25^{-} \mathrm{CD} 44^{+}$ $\mathrm{T}$ cells from Salmonella vector-immunized mice. ${ }^{137}$ TGF- $\beta$ neutralization also impacted the expression of Foxp3 by the $\mathrm{T}_{\text {reg }}$ cells enabling IL-17 to be augmented, which would account for the loss of function and ultimately protection. Thus, TGF- $\beta$ is an essential regulatory element induced by Salmonella-CFA/I therapeutic.

In an attempt to disrupt the protective capacity of CFA/I fimbriae, a mutant was developed to alter the cell surface expression of the fimbriae. This mutant bears only the $c f a A B$ portion of the operon and lacks the genes for the outer membrane usher protein $c f a C$, and minor fimbrial subunit $c f a E$, and is referred to as Salmonella-CFA/ $\mathrm{I}_{\text {(intracellular) }}$ (Salmonella-CFA/I IC). ${ }^{138}$ This restricted the major subunit $\mathrm{CfaB}$ primarily to the Salmonella's periplasm. Upon oral vaccination, mice showed reduced fecal SIgA and reduced serum IgG Abs to the fimbriae but remained as effective in protecting mice against EAE as did adoptive transfer of their $\mathrm{T}_{\mathrm{reg}}$ cells into EAE recipients. ${ }^{138}$ What was particularly interesting of this finding was the difference in cytokine profiles from Salmonella-CFA/I-vaccinated mice. Examination of cytokine production by $\mathrm{T}_{\text {reg }}$ cells from Salmonella-CFA $/ \mathrm{I}_{\mathrm{IC}}$-treated EAE mice revealed no change in TGF- $\beta$ production but considerably augmented IFN $-\gamma$ and IL13 production relative to similarly treated mice with Salmonella-CFA/I. ${ }^{138}$ The percentage of Foxp $3^{+} \mathrm{T}_{\text {reg }}$ cells was similar. To test the relevance of the observed IFN- $\gamma$ and IL-13, in vivo Ab neutralization studies were conducted. Adoptive transfer of Salmonella-CFA/I IC's $\mathrm{T}_{\text {reg }}$ cells into EAE recipients neutralized of their IFN- $\gamma$ using a $\mathrm{mAb}$ resulted in no differences in susceptibility to EAE, and both groups of mice given $\mathrm{T}_{\text {reg }}$ cells with normal rat IgG or rat anti-mouse IFN $-\gamma \mathrm{mAb}$ showed protection against disease. In contrast, EAE recipients neutralized of their IL-13 using a polyclonal anti-IL-13 Ab and adoptively transferred with SalmonellaCFA/I IC's $T_{\text {reg }}$ cells lost their protection further showing the importance of IL-13 in defense against EAE. ${ }^{138}$ This further implicated the ability of IL-13 to directly affect $\mathrm{T}_{\text {reg }}$ cell function or enhance the action of $\mathrm{T}_{\text {reg }}$ cells. ${ }^{138}$ Thus, these collective studies show the effectiveness of Salmonella-CFA/I and Salmonella-CFA/I IC as therapeutics to defend against EAE.

\section{SALMONELLA-CFA/I AS AN ANTI-INFLAMMATORY VACCINE FOR AN INFLAMMATORY MODEL OF ARTHRITIS}

Rheumatoid arthritis (RA) is an autoimmune disorder and chronic inflammatory disease of the joints impacting $\sim 1 \%$ of 
the population in North America and the United Kingdom, ${ }^{139}$ with women being three times more likely to be afflicted than men. ${ }^{139,140}$ Although the etiology of this disease remains to be discerned, it is manifested as a chronic synovitis and progressive destruction of the joints, leukocyte infiltrates and cartilage destruction and bone erosion. This destruction is believed to be supported and perpetuated by proinflammatory cytokines. Past studies have indeed shown that proinflammatory cytokines are overexpressed in RA joints (reviewed in Feldmann et al., ${ }^{141}$ Brennan et al. ${ }^{142}$ and Kannan et al. ${ }^{143}$ ). To understand how such cytokines are regulated, a rodent model sharing many of the same features for human disease (reviewed in Kannan et al. ${ }^{143}$ ) was developed. This autoimmune disease, collagen-induced arthritis (CIA), is induced by immunizing rodents, typically with heterologous (bovine or chick) type II collagen in combination with adjuvant, to elicit immune attack of the host's native collagen. Thus, components of both the innate and adaptive immune systems are involved. Emphasis on regulating proinflammatory cytokines, particularly TNF- $\alpha$, is key to minimizing disease as it can be detected in joints of RA patients. ${ }^{144-146}$ Treatment with TNF- $\alpha$ antagonists decreases inflammation and attenuates the destruction of cartilage and bone. ${ }^{141,147-151}$ Such treatment is also believed to inhibit other inflammatory cytokines, including IL-1, IL-6, IL-8 and granulocyte macrophages colony-stimulating factor. ${ }^{141,142}$ Components of both the adaptive and innate immune systems contribute as a source for TNF- $\alpha$ and other proinflammatory cytokines. ${ }^{143,152,153}$ IFN- $\gamma$ also contributes to disease, but it is phase dependent ${ }^{154-157}$. Th17 cells, which can regulate both Th1 and Th2 cells, ${ }^{158,159}$ may be important for mediating RA disease as $\mathrm{ICOS}^{-1-} \mathrm{DBA} / 1$ mice showed depressed IL-17 production, but not TNF- $\alpha$ or IFN- $\gamma$, and still conferred complete resistance to CIA. ${ }^{160} \mathrm{IL}-17$ is also expressed by the human synovium and is particularly elevated in patients with RA $^{161,162}$ and is IL-23 dependent. ${ }^{163}$ In vivo neutralization of IL-17 results in significantly reduced CIA and could also lessen the progression of the established disease. ${ }^{164}$

Given the results from the EAE studies, we queried whether Salmonella-CFA/I would be effective in treating CIA, a rodent model for RA. ${ }^{153}$ DBA/I mice are susceptible to chick or bovine collagen II (CII) challenge, and develop a progressive disease affecting multiple joints. ${ }^{153,165}$ As such, DBA/1 mice were orally dosed with Salmonella-CFA/I, Salmonella vector or PBS 7 days before CII challenge. Mice were followed for a course of 42 days, and Salmonella-CFA/I protected against CIA as evidenced by minimal clinical disease and significantly reduced incidence unlike mice treated with the Salmonella vector or PBS. ${ }^{166}$ The observed reduction in disease was supported by the production of the cytokines IL-4, IL-10 and TGF- $\beta$ by CD4 ${ }^{+}$T cells. In addition, mononuclear cells from Salmonella-CFA/I-treated animals had decreased levels of TNF- $\alpha$, IL-1 $\beta$, IL- 6 and IL-27. ${ }^{166}$ To distill which CD4 ${ }^{+}$T cells were responsible for the regulatory and anti-inflammatory cytokines in DBA/1 mice void of disease, mice were orally vaccinated with Salmonella-CFA/I, and cytokine profiles from
$\mathrm{CD} 25^{+} \mathrm{CD} 4{ }^{+}$and $\mathrm{CD} 25^{-} \mathrm{CD} 4{ }^{+} \mathrm{T}$ cells were assessed. The $\mathrm{CD} 25^{+} \mathrm{CD} 44^{+} \mathrm{T}$ cells produced significantly more IL-4, IL-10 and TGF- $\beta$ than the CD25- $\mathrm{T}$ cells. Interestingly, IFN- $\gamma$ and IL-17 were significantly elevated relative to $\mathrm{CD} 25^{-} \mathrm{CD} 4{ }^{+} \mathrm{T}$ cells but less than $\mathrm{CD} 25^{+} \mathrm{CD} 4{ }^{+} \mathrm{T}$ cells from Salmonella vector-immunized mice. ${ }^{166}$ As the $\mathrm{CD} 25^{+} \mathrm{CD} 4{ }^{+} \mathrm{T}$ cells from similarly vaccinated mice were highly protective against EAE, ${ }^{68}$ adoptive transfer studies were performed to measure the potency of these $T_{\text {reg }}$ cells in conferring protection against CIA. Surprisingly, neither the individual $\mathrm{CD} 25^{+} \mathrm{CD} 4{ }^{+}$nor $\mathrm{CD} 25^{-} \mathrm{CD} 4{ }^{+}$T-cell subset was adequate in treating CIA relative to whole $\mathrm{CD} 4^{+}$T-cell isolates with respect to disease onset and mice with reduced clinical disease. ${ }^{166}$ Thus, it appeared that both $\mathrm{CD} 25^{+} \mathrm{CD} 4{ }^{+}$and $\mathrm{CD} 25^{-} \mathrm{CD} 4{ }^{+} \mathrm{T}$ cells were required for protection against CIA. Subsequently, adoptive transfer studies using total $\mathrm{CD}^{+}{ }^{+} \mathrm{T}$ cells in combination with anti-IL-4 mAb or anti-TGF- $\beta$ mAb were performed and revealed that inhibition of either cytokine resulted in disease and loss of the protective response. ${ }^{166}$ Collectively, these data showed that Salmonella-CFA/I could treat CIA via the induction of diverse populations of $\mathrm{T}_{\text {reg }}$ cells.

As neither $\mathrm{CD} 25^{+}$nor $\mathrm{CD} 25^{-} \mathrm{CD} 4{ }^{+} \mathrm{T}$ cells could completely protect following adoptive transfer into DBA/1 mice, our data suggested that perhaps a different $\mathrm{T}_{\text {reg }}$-cell subset was being induced. To investigate such a possibility, the Salmonella-CFA/I-induced $\mathrm{CD} 4^{+} \mathrm{T}$ cells were screened for expression of alternative $\mathrm{T}_{\text {reg }}$-cell markers other than CD25. One such alternative is $\mathrm{CD} 39$. These $\mathrm{CD} 39^{+} \mathrm{T}_{\text {reg }}$ cells are also able to suppress Th17 cells, and their absence has been linked to MS. ${ }^{167}$ Specifically, CD39 is an ectonuleoside triphosphate diphosphohydrolase, and it is expressed on the cell surface of Foxp3 ${ }^{+} \mathrm{T}_{\text {reg }}$ cells, dampening proinflammatory cells by ultimately converting proinflammatory extracellular ATP to anti-inflammatory adenosine. ${ }^{166,168,169}$ Subsequent evaluation of $\mathrm{CD} 39^{+}$expression was conducted in $\mathrm{C} 57 \mathrm{BL} / 6$ male mice, which also are susceptible to arthritis. ${ }^{170}$ Thus, CIA mice were orally dosed with Salmonella-CFA/I, and it was revealed that only half of the $\mathrm{CD} 39^{+} \mathrm{CD}^{+}{ }^{+} \mathrm{T}$ cells was Foxp3 ${ }^{+}$ $\mathrm{CD} 25^{+}{ }_{\mathrm{CD}} 4^{+}$, although $\mathrm{CD} 39$ was also expressed on the $\mathrm{CD} 25^{-} \mathrm{CD} 4{ }^{+} \mathrm{T}$ cells. ${ }^{170}$ To determine whether these CD $39^{+}$ $\mathrm{T}$ cells were protective against disease, $\mathrm{C} 57 \mathrm{BL} / 6$ mice were adoptively transferred with $\mathrm{CD} 39^{+} \mathrm{CD} 4{ }^{+}$or $\mathrm{CD} 39^{-} \mathrm{CD} 4{ }^{+}$ $\mathrm{T}$ cells from Salmonella-CFA/I- or Salmonella vector-dosed mice into recipients challenged 14 days earlier with CIA. Only mice receiving $\mathrm{CD} 39^{+} \mathrm{CD} 4{ }^{+} \mathrm{T}$ cells from Salmonella-CFA/Idosed mice were protected against CIA, indicating that again the CFA/I fimbriae are essential in stimulating this therapeutic subset of $\mathrm{T}_{\mathrm{reg}}$ cells. As these $\mathrm{CD} 39^{+} \mathrm{CD} 4{ }^{+} \mathrm{T}$ cells were composed of both Foxp3 ${ }^{+}$and Foxp3 ${ }^{-}$cells, further analysis was performed to determine whether Foxp3 ${ }^{+}$ $\mathrm{CD} 39^{+} \mathrm{CD} 4{ }^{+} \mathrm{T}$ cells were protective against CIA. Notably, CIA recipients given either $\mathrm{Foxp} 33^{+} \mathrm{CD} 39^{+} \mathrm{CD} 4{ }^{+}$or Foxp $3^{-} \mathrm{CD} 39^{+} \mathrm{CD}^{+} \mathrm{T}$ cells protected equally to disease but not as effectively as total $\mathrm{CD} 39^{+} \mathrm{CD} 4{ }^{+} \mathrm{T}$ cells. ${ }^{170}$ These subsets were further teased to discern how they differ. Cytokine analysis revealed that IL-10 and TGF- $\beta$ segregated 
with $\mathrm{Foxp}^{+}{ }^{+} \mathrm{CD} 39^{+} \mathrm{CD}^{+}{ }^{+}$and $\mathrm{Foxp}^{-} \mathrm{CD}^{-}{ }^{+} \mathrm{CD} 4{ }^{+}$ $\mathrm{T}$ cells, respectively. ${ }^{170}$ Neutralization of TGF- $\beta$ reduced the percentage of CD39 expression, implicating the importance of TGF- $\beta$ for induction of CD39. ${ }^{170}$

\section{CONCLUSIONS}

Outside of our studies, there have only been a few reports where bacterial infections have been used to subdue EAE, ${ }^{171,172}$ and even less for CIA. However, it is important to emphasize that the induction of $\mathrm{T}_{\text {reg }}$ cells is mediated not so much by the attenuated Salmonella vaccine strain as these cells are induced by the fimbriae or the combination of bacteria with fimbriae. Current studies are addressing these possibilities. Nonetheless, our studies demonstrate the feasibility of a simple oral treatment with Salmonella-CFA/I to render protection against EAE and CIA without having previous knowledge of the auto-Ag. Consequently, in a bystander fashion, both fimbriae- and PLP $139-151^{-s p e c i f i c, ~ T G F-~} \beta$-producing, FoxP3 ${ }^{+} \mathrm{CD} 25^{+} \mathrm{CD} 4{ }^{+} \mathrm{T}$ cells were induced for $\mathrm{EAE}$ and CII-specific, IL-10-producing $\mathrm{FoxP}^{+}{ }^{+} \mathrm{CD} 39^{+}$and TGF- $\beta$ producing FoxP $3{ }^{-} \mathrm{CD} 39^{+} \mathrm{CD} 4{ }^{+} \mathrm{T}$ cells. For the protective $\mathrm{T}_{\text {reg }}$ cells in CIA, co-expression of CD25 did not specifically segregate with either subset. ${ }^{170}$ The advantage of using Salmonella-CFA/I is that intervention of autoimmunity can be achieved upon vaccination with an innocuous Ag, and in this case the side-effect would be the additional protection against the diarrheal diseases, ETEC and salmonellosis. Moreover, this therapeutic can be administered orally enabling patient compliance. Additionally, this approach does not polyclonally activate $\mathrm{T}_{\text {reg }}$ cells, which have been shown to have a cataclysmic outcome. ${ }^{173}$

\section{CONFLICT OF INTEREST}

The authors declare no conflict of interest.

\section{ACKNOWLEDGEMENTS}

This work was supported by the Public Health Service Grants AI-41123 and P01 AT-004986-05.

1 Svennerholm AM, Lundgren A. Recent progress toward an enterotoxigenic Escherichia coli vaccine. Expert Rev Vaccines 2012; 11: 495-507.

2 Qadri F, Svennerholm AM, Faruque AS, Sack RB. Enterotoxigenic Escherichia coli in developing countries: epidemiology, microbiology, clinical features, treatment, and prevention. Clin Microbiol Rev 2005; 18: $465-483$

3 Hill DR, Beeching NJ. Travelers' diarrhea. Curr Opin Infect Dis 2010; 23: 481-487.

4 Field M, Graf LH, Laird WJ, Smith PL. Heat-stable enterotoxin of Escherichia coli: in vitro effects on guanylate cyclase activity, cyclic GMP concentration and ion transport in the small intestine. Proc Nat Acad Sci USA 1978; 75: 2800-2804.

5 Clements JD, Finkelstein RA. Demonstration of shared and unique immunologic determinants in enterotoxins from V. cholerae and $E$. coli. Infect Immun 1978; 22: 709-713.

6 Spangler BD. Structure and function of cholera toxin and the related Escherichia coli heat-labile enterotoxin. Microbiol Rev 1992; 56 622-647.

7 Evans DJ Jr, Evans DG. Colonization factor antigens of human pathogens. Cur Top Microbiol Immunol 1990; 151: 129-145.
8 de Graaf FK, Gaastra W. Fimbriae of enterotoxigenic Escherichia coli. In: Klemm P (ed) Fimbriae: Adhesins, Biogenics, Genetics, and Vaccines. CRC Press: Boca Raton, FL, USA, 1994. pp 53-83.

9 Tchesnokova V, McVeigh AL, Kidd B, Yakovenko O, Thomas WE, Sokurenko EV et al. Shear-enhanced binding of intestinal colonization factor antigen I of enterotoxigenic Escherichia coli. Mol Microbiol 2010; 76: 489-502.

10 Li YF, Poole S, Rasulova F, McVeigh AL, Savarino SJ, Xia D. A receptorbinding site as revealed by the crystal structure of $\mathrm{CfaE}$, the colonization factor antigen I fimbrial adhesin of enterotoxigenic Escherichia coli. J Biol Chem 2007; 282: 23970-23980.

11 Jansson L, Tobias J, Lebens M, Svennerholm AM, Teneberg S. The major subunit, $\mathrm{CfaB}$, of colonization factor antigen I from enterotoxigenic Escherichia coli is a glycosphingolipid binding protein. Infect Immun 2006; 74: 3488-3497.

12 Pascual DW, Ochoa-Repáraz J, Rynda A, Yang X. Tolerance in the absence of auto-antigen. Endocr Metab Immune Disord Drug Targets 2007; 7: 203-210.

13 Black RE, Merson MH, Rowe B, Taylor PR, Abdul Alim AR, Gross RJ et al. Enterotoxigenic Escherichia coli diarrhoea: acquired immunity and transmission in an endemic area. Bull World Health Organ 1981; 59: 263-268.

14 Black RE, Brown KH, Becker S, Alim AR, Huq I. Longitudinal studies of infectious diseases and physical growth of children in rural Bangladesh. II. Incidence of diarrhea and association with known pathogens. Am J Epidemiol 1982; 115: 315-324.

15 Cravioto A, Reyes RE, Ortega R, Fernández G, Hernández R, López D. Prospective study of diarrhoeal disease in a cohort of rural Mexican children: incidence and isolated pathogens during the first two years of life. Epidemiol Infect 1988; 101: 123-134.

16 Levine MM. Escherichia coli that cause diarrhea: enterotoxigenic, enteropathogenic, enteroinvasive, enterohemorrhagic, and enteroadherent. J Infect Dis 1987; 155: 377-389.

17 Levine MM, Girón JA, Noriega FR. Fimbrial vaccines. In: Klemm P (ed) Fimbriae: Adhesins, Biogenics, Genetics, and Vaccines. CRC Press: Boca Raton, FL, USA, 1994. pp 255-270.

18 Anantha RP, McVeigh AL, Lee LH, Agnew MK, Cassels FJ, Scott DA et al. Evolutionary and functional relationships of colonization factor antigen and other class 5 adhesive fimbriae of enterotoxigenic Escherichia coli. Infect Immun 2004; 72: 7190-7201.

19 Li YF, Poole S, Nishio K, Jang K, Rasulova F, McVeigh A et al. Structure of CFA/l fimbriae from enterotoxigenic Escherichia coli. Proc Natl Acad Sci USA 2009; 106: 10793-10798.

20 Li YF, Poole S, Rasulova F, Esser L, Savarino SJ, Xia D. Crystallization and preliminary X-ray diffraction analysis of $\mathrm{CfaE}$, the adhesive subunit of the CFA/l fimbriae from human enterotoxigenic Escherichia coli. Acta Crystallogr Sect F Struct Biol Cryst Commun 2006; 62(Pt 2), 121-124.

21 Edelman R, Russell RG, Losonsky G, Tall BD, Tacket CO, Levine MM et al. Immunization of rabbits with enterotoxigenic $E$. coli colonization factor antigen (CFA/I) encapsulated in biodegradable microspheres of poly (lactide-co-glycolide). Vaccine 1993; 11: 155-158.

22 Evans DG, Graham DY, Evans DJ Jr. Administration of purified colonization factor antigens (CFA/I, CFA/II) of enterotoxigenic Escherichia coli to volunteers. Response to challenge with virulent enterotoxigenic Escherichia coli. Gastroenterology 1984; 87: 934-940.

23 Levine M, Morris JG, Losonsky G, Boedeker E, Rowe B. Fimbriae (pili) adhesins as vaccine. In: Lark D L, Normark S, Uhlin B-E, Wolf-Watz $\mathrm{H}$ (eds) Protein-Carbohydrate Interactions in Biological Systems: Molecular Biology of Microbial Pathogenicity. Academic Press: London, UK, 1986. pp 143-145.

24 Schmidt M, Kelly EP, Tseng LY, Boedeker EC. Towards an oral E. coli pilus vaccine for travelers diarrhea: susceptibility to proteolytic digestion. Gastroenterology 1985; 82: A1575.

25 Reid RH, Boedeker EC, McQueen CE, Davis D, Tseng LY, Kodak J et al. Preclinical evaluation of microencapsulated CFA/II oral vaccine against enterotoxigenic E. coli. Vaccine 1993; 11: 159-167.

26 Sánchez J, Holmgren J. Virulence factors, pathogenesis and vaccine protection in cholera and ETEC diarrhea. Curr Opin Immunol 2005; 17 388-398.

27 Boedeker EC. Vaccines for enterotoxigenic Escherichia coli: current status. Curr Opin Gastroenterol 2005; 21: 15-19.

28 Galen JE, Pasetti MF, Tennant S, Ruiz-Olvera P, Sztein MB, Levine MM Salmonella enterica serovar Typhi live vector vaccines finally come of age. Immunol Cell Biol 2009; 87: 400-412. 
29 McGregor AC, Waddington CS, Pollard AJ. Prospects for prevention of Salmonella infection in children through vaccination. Curr Opin Infect Dis 2013; 26: 254-262.

30 Desin TS, Köster W, Potter AA. Salmonella vaccines in poultry: past, present and future. Expert Rev Vaccines 2013; 12: 87-96.

31 Pasetti MF, Levine MM, Sztein MB. Animal models paving the way for clinical trials of attenuated Salmonella enterica serovar Typhi live oral vaccines and live vectors. Vaccine 2003; 21: 401-418.

32 Curtiss R 3rd, Xin W, Li Y, Kong W, Wanda SY, Gunn B et al. New technologies in using recombinant attenuated Salmonella vaccine vectors. Crit Rev Immunol 2010; 30: 255-270.

33 Mestecky J, Nguyen H, Czerkinsky C, Kiyono H. Oral immunization: an update. Curr Opin Gastroenterol 2008; 24: 713-719.

34 Curtiss R 3rd. Bacterial infectious disease control by vaccine development. J Clin Invest 2002; 110: 1061-1066.

35 Wu S, Pascual DW, VanCott JL, McGhee JR, Maneval DR Jr, Levine MM et al. Immune responses to novel Escherichia coli and Salmonella typhimurium vectors that express colonization factor antigen I (CFA/I) of enterotoxigenic $E$. coli in the absence of the CFA/l positive regulator cfaR. Infect Immun 1995; 63: 4933-4938.

36 Yang X, Suo Z, Thornburg T, Holderness K, Walters N, Kellerman L et al. Expression of Escherichia coli virulence usher protein attenuates wildtype Salmonella. Virulence 2012; 3: 29-42.

37 Cao L, Suo Z, Lim T, Jun S, Deliorman M, Riccardi C et al. Role of overexpressed CFA/l fimbriae in bacterial swimming. Phys Biol 2012; 9: 036005

38 Pascual DW, Hone DM, Hall S, van Ginkel FW, Yamamoto M, Walters N et al. Expression of recombinant enterotoxigenic Escherichia coli colonization factor antigen I by Salmonella typhimurium elicits a biphasic $T$ helper cell response. Infect Immun 1999; 67: 6249-6256.

39 Nauciel C, Espinasse-Maes F. Role of gamma interferon and tumor necrosis factor alpha in resistance to Salmonella typhimurium infection. Infect Immun 1992; 60: 450-454.

40 Killar LM, Eisenstein TK. Delayed-type hypersensitivity and immunity to Salmonella typhimurium. Infect Immun 1986; 52: 504-508.

41 Pope M, Kotlarski I. Detection of Salmonella-specific L3T4 + and Lyt$2+\mathrm{T}$ cells which can proliferate in vitro and mediate delayed-type hypersensitivity reactivity. Immunol 1994; 81: 183-191.

42 Mastroeni P, Villareal-Ramos B, Hormaeche CE. Role of T cells, TNF alpha and IFN gamma in recall of immunity to oral challenge with virulent salmonellae in mice vaccinated with live attenuated aro- Salmonella vaccines. Microb Pathog 1992; 13: 477-491.

43 VanCott JL, Staats HF, Pascual DW, Roberts M, Chatfield SN, Yamamoto $\mathrm{M}$ et al. Regulation of mucosal and systemic antibody responses by $\mathrm{T}$ helper cell subsets, macrophages, and derived cytokines following oral immunization with live recombinant Salmonella. J Immunol 1996; 156: 1504-1514.

44 Ravindran R, Foley J, Stoklasek T, Glimcher LH, McSorley SJ. Expression of T-bet by CD4 T cells is essential for resistance to Salmonella infection. $\mathrm{J}$ Immunol 2005; 175: 4603-4610.

45 Yang DM, Fairweather N, Button LL, McMaster WR, Kahl LP, Liew FY. Oral Salmonella typhimurium (AroA-) vaccine expressing a major leishmanial surface protein (gp63) preferentially induces T helper 1 cells and protective immunity against leishmaniasis. J Immunol 1990; 145: 2281-2285.

46 Fouts TR, Tuskan RG, Chada S, Hone DM, Lewis GK. Construction and immunogenicity of Salmonella typhimurium vaccine vectors that express HIV-1 gp120. Vaccine 1995; 13: 1697-1705.

47 Xu D, McSorley SJ, Chatfield SN, Dougan G, Liew FY. Protection against Leishmania major infection in genetically susceptible BALB/c mice by gp63 delivered orally in attenuated Salmonella typhimurium (AroA- AroD-). Immunol 1995; 85: 1-7.

48 Hess J, Gentschev I, Miko D, Welzel M, Ladel C, Goebel W et al. Superior efficacy of secreted over somatic antigen display in recombinant Salmonella vaccine induced protection against listeriosis. Proc Natl Acad Sci USA 1996; 93: 1458-1463.

49 Walters N, Trunkle T, Sura M, Pascual DW. Enhanced immunoglobulin A response and protection against Salmonella enterica serovar Typhimurium in the absence of the substance $\mathrm{P}$ receptor. Infect Immun 2005; 73: 317-324.

50 Tite JP, Dougan G, Chatfield SN. The involvement of tumor necrosis factor in immunity to Salmonella infection. J Immunol 1991; 147: 3161-3164.
51 Pascual DW, Trunkle T, Sura J. Fimbriated Salmonella enterica serovar Typhimurium abates initial inflammatory responses by macrophages. Infect Immun 2002; 70: 4273-4281.

52 Miller SI, Ernst RK, Bader MW. LPS, TLR4 and infectious disease diversity. Nat Rev Microbiol 2005; 3: 36-46.

53 Swanborg RH. Experimental autoimmune encephalomyelitis in rodents as a model for human demyelinating disease. Clin Immunol Immunopathol 1995; 77: 4-13.

54 Smith ME, Eller NL, McFarland HF, Racke MK, Raine CS. Age dependence of clinical and pathological manifestations of autoimmune demyelination. Implications for multiple sclerosis. Am J Pathol 1999; 155: $1147-1161$.

55 Hafler DA. Multiple sclerosis. J Clin Invest 2004; 113: 788-794.

56 Batoulis $\mathrm{H}$, Addicks K, Kuerten S. Emerging concepts in autoimmune encephalomyelitis beyond the CD4/TH1 paradigm. Ann Anat 2010; 192: 179-193.

57 Prat E, Martin R. The immunopathogenesis of multiple sclerosis. J Rehab Res Dev 2002; 39: 187-200.

58 Steinman L, Martin R, Bernard C, Conlon P, Oksenberg JR. Multiple sclerosis: deeper understanding of its pathogenesis reveals new targets for therapy. Annu Rev Neurosci 2002; 25: 491-505.

59 Inglese M. Multiple sclerosis: new insights and trends. AJNR Am J Neuroradiol 2006; 27: 954-957.

60 Fujinami RS. Can virus infections trigger autoimmune disease? J Autoimmun 2001; 16: 229-234.

61 von Büdingen HC, Tanuma N, Villoslada P, Ouallet JC, Hauser SL, Genain CP. Immune responses against the myelin/oligodendrocyte glycoprotein in experimental autoimmune demyelination. J Clin Immunol 2001; 21: 155-170.

62 Miller SD, Katz-Levy Y, Neville KL, Vanderlugt CL. Virus-induced autoimmunity: epitope spreading to myelin autoepitopes in Theiler's virus infection of the central nervous system. Adv Virus Res 2001; 56: 199-217.

63 Swanborg RH. Experimental autoimmune encephalomyelitis in the rat: lessons in T-cell immunology and autoreactivity. Immunol Rev 2001; 184: 129-135.

64 Kuchroo VK, Anderson AC, Waldner H, Munder M, Bettelli E, Nicholson LB. T cell response in experimental autoimmune encephalomyelitis (EAE): role of self and cross-reactive antigens in shaping, tuning, and regulating the autopathogenic T cell repertoire. Annu Rev Immunol 2002; 20: 101-123.

65 Martin Mdel P, Monson NL. Potential role of humoral immunity in the pathogenesis of multiple sclerosis (MS) and experimental autoimmune encephalomyelitis (EAE). Front Biosci 2007; 12: 2735-2749.

66 St Louis J, Uniyal S, Xu L, Chan E, Singh B, Chan BM et al. Tolerance induction by acylated peptides: suppression of EAE in the mouse with palmitoylated PLP peptides. J Neuroimmunol 2001; 115: 79-90.

67 Hall SW, Cooke A. Autoimmunity and inflammation: murine models and translational studies. Mamm Genome 2011; 22: 377-389.

68 Ochoa-Repáraz J, Riccardi C, Rynda A, Jun S, Callis G, Pascual DW. Regulatory $\mathrm{T}$ cell vaccination without autoantigen protects against experimental autoimmune encephalomyelitis. J Immunol 2007; 178: 1791-1799.

69 Stromnes IM, Goverman JM. Active induction of experimental allergic encephalomyelitis. Nat Protoc 2006; 1: 1810-1819.

70 McRae BL, Vanderlugt CL, Dal Canto MC, Miller SD. Functional evidence for epitope spreading in the relapsing pathology of experimental autoimmune encephalomyelitis. J Exp Med 1995; 182: 75-85.

71 Tuohy VK, Yu M, Yin L, Mathisen PM, Johnson JM, Kawczak JA. Modulation of the IL-10/IL-12 cytokine circuit by interferon-beta inhibits the development of epitope spreading and disease progression in murine autoimmune encephalomyelitis. J Neuroimmunol 2000; 111: 55-63.

72 Yin L, Yu M, Edling AE, Kawczak JA, Mathisen PM, Nanavati T et al. Pre-emptive targeting of the epitope spreading cascade with genetically modified regulatory $T$ cells during autoimmune demyelinating disease. J Immunol 2001; 167: 6105-6112.

73 Cua DJ, Sherlock J, Chen Y, Murphy CA, Joyce B, Seymour B et al. Interleukin-23 rather than interleukin-12 is the critical cytokine for autoimmune inflammation of the brain. Nature 2003; 421: 744-748.

74 Becher B, Durell BG, Noelle RJ. Experimental autoimmune encephalitis and inflammation in the absence of interleukin-12. J Clin Invest 2002; 110: 493-497. 
75 Zhang GX, Gran B, Yu S, Li J, Siglienti I, Chen X et al. Induction of experimental autoimmune encephalomyelitis in IL-12 receptor- $\beta 2$-deficient mice: IL-12 responsiveness is not required in the pathogenesis of inflammatory demyelination in the central nervous system. J Immunol 2003; 170: 2153-2160.

76 Park H, Li Z, Yang XO, Chang SH, Nurieva R, Wang YH et al. A distinct lineage of $\mathrm{CD} 4 \mathrm{~T}$ cells regulates tissue inflammation by producing interleukin 17. Nat Immunol 2005; 6: 1133-1141.

77 Hofstetter HH, Ibrahim SM, Koczan D, Kruse N, Weishaupt A, Toyka KV et al. Therapeutic efficacy of IL-17 neutralization in murine experimental autoimmune encephalomyelitis. Cell Immunol 2005; 237: 123-130.

78 Komiyama Y, Nakae S, Matsuki T, Nambu A, Ishigame H, Kakuta S et al. IL-17 plays an important role in the development of experimental autoimmune encephalomyelitis. J Immunol 2006; 177: 566-573.

79 Sutton C, Brereton C, Keogh B, Mills KH, Lavelle EC. A crucial role for interleukin (IL)-1 in the induction of IL-17-producing T cells that mediate autoimmune encephalomyelitis. J. Exp Med 2006; 203: 1685-1691.

80 Inobe J, Slavin AJ, Komagata Y, Chen Y, Liu L, Weiner HL. IL-4 is a differentiation factor for transforming growth factor- $\beta$ secreting Th3 cells and oral administration of IL-4 enhances oral tolerance in experimental allergic encephalomyelitis. Eur J Immunol 1998; 28: 2780-2790.

81 Zhang X, Koldzic DN, Izikson L, Reddy J, Nazareno RF, Sakaguchi S et al. IL-10 is involved in the suppression of experimental autoimmune encephalomyelitis by $\mathrm{CD} 25+\mathrm{CD} 4+$ regulatory $\mathrm{T}$ cells. Int Immunol 2004; 16: 249-256.

82 Sun JB, Xiao BG, Lindblad M, Li BL, Link H, Czerkinsky $\mathrm{C}$ et al. Oral administration of cholera toxin $B$ subunit conjugated to myelin basic protein protects against experimental autoimmune encephalomyelitis by inducing transforming growth factor- $\beta$-secreting cells and suppressing chemokine expression. Int Immunol 2000; 12: 1449-1457.

83 Kohm AP, Carpentier PA, Anger HA, Miller SD. Cutting edge: CD4 + $\mathrm{CD} 25+$ regulatory $\mathrm{T}$ cells suppress antigen-specific autoreactive immune responses and central nervous system inflammation during active experimental autoimmune encephalomyelitis. J Immunol 2002; 169: 4712-4716.

84 Tran EH, Prince EN, Owens T. IFN-gamma shapes immune invasion of the central nervous system via regulation of chemokines. J Immunol 2000; 164: 2759-2768.

85 Ito A, Bebo BF Jr, Matejuk A, Zamora A, Silverman M, Fyfe-Johnson A et al. Estrogen treatment down-regulates TNF- $\alpha$ production and reduces the severity of experimental autoimmune encephalomyelitis in cytokine knockout mice. J Immunol 2001; 167: 542-552.

86 Willenborg DO, Fordham SA, Staykova MA, Ramshaw IA, Cowden WB. IFN- $\gamma$ is critical to the control of murine autoimmune encephalomyelitis and regulates both in the periphery and in the target tissue: a possible role for nitric oxide. J Immunol 1999; 163: 5278-5286.

87 Chu CQ, Wittmer S, Dalton DK. Failure to suppress the expansion of the activated CD4 T cell population in interferon $\gamma$-deficient mice leads to exacerbation of experimental autoimmune encephalomyelitis. J Exp Med 2000; 192: 123-128.

88 Körner H, Lemckert FA, Chaudhri G, Etteldorf S, Sedgwick JD. Tumor necrosis factor blockade in actively induced experimental autoimmune encephalomyelitis prevents clinical disease despite activated $\mathrm{T}$ cell infiltration to the central nervous system. Eur J Immunol 1997; 27: 1973-1981.

89 Khoury SJ, Hancock WW, Weiner HL. Oral tolerance to myelin basic protein and natural recovery from experimental autoimmune encephalomyelitis are associated with downregulation of inflammatory cytokines and differential upregulation of transforming growth factor $\beta$, interleukin 4, and prostaglandin E expression in the brain. J Exp Med 1992; 176: $1355-1364$.

90 Falcone M, Rajan AJ, Bloom BR, Brosnan CF. A critical role for IL-4 in regulating disease severity in experimental allergic encephalomyelitis as demonstrated in IL-4-deficient C57BL/6 mice and BALB/C mice. $\mathrm{J}$ Immunol 1998; 160: 4822-4830.

91 Mendel I, Natarajan K, Ben-Nun A, Shevach EM. A novel protective model against experimental allergic encephalomyelitis in mice expressing a transgenic TCR-specific for myelin oligodendrocyte glycoprotein. $J$ Neuroimmunol 2004; 149: 10-21.

92 Cua DJ, Groux H, Hinton DR, Stohlman SA, Coffman RL. Transgenic interleukin 10 prevents induction of experimental autoimmune encephalomyelitis. J Exp Med 1999; 189: 1005-1010.

93 Legge KL, Min B, Bell JJ, Caprio JC, Li L, Gregg RK et al. Coupling of peripheral tolerance to endogenous interleukin 10 promotes effective modulation of myelin-activated $\mathrm{T}$ cells and ameliorates experimental allergic encephalomyelitis. J Exp Med 2000; 191: 2039-2052.

94 Slavin AJ, Maron R, Weiner HL. Mucosal administration of IL-10 enhances oral tolerance in autoimmune encephalomyelitis and diabetes. Int Immunol 2001; 13: 825-833.

95 Karpus WJ, Swanborg RH. CD4 + suppressor cells inhibit the function of effector cells of experimental autoimmune encephalomyelitis through a mechanism involving transforming growth factor- $\beta$. J Immunol 1991; 146: $1163-1168$

96 Racke MK, Dhib-Jalbut S, Cannella B, Albert PS, Raine CS, McFarlin DE. Prevention and treatment of chronic relapsing experimental allergic encephalomyelitis by transforming growth factor-beta 1 . J Immunol 1991; 146: 3012-3017.

97 Miller A, Lider O, Roberts AB, Sporn MB, Weiner HL. Suppressor T cells generated by oral tolerization to myelin basic protein suppress both in vitro and in vivo immune responses by the release of transforming growth factor beta after antigen-specific triggering. Proc Natl Acad Sci USA 1992; 89: 421-425.

98 Pot C, Apetoh L, Awasthi A, Kuchroo VK. Induction of regulatory Tr1 cells and inhibition of TH17 cells by IL-27. Semin Immunol 2011; 23 438-445.

99 Fitzgerald DC, Ciric B, Touil T, Harle H, Grammatikopolou J, Das Sarma J et al. Suppressive effect of IL-27 on encephalitogenic Th17 cells and the effector phase of experimental autoimmune encephalomyelitis. $\mathrm{J}$ Immunol 2007; 179: 3268-3275.

100 Fitzgerald DC, Zhang GX, El-Behi M, Fonseca-Kelly Z, Li H, Yu S et al. Suppression of autoimmune inflammation of the central nervous system by interleukin 10 secreted by interleukin 27-stimulated T cells. Nat Immunol 2007; 8: 1372-1379.

101 Bettini M, Vignali DA. Regulatory T cells and inhibitory cytokines in autoimmunity. Curr Opin Immunol 2009; 21: 612-618.

102 Paust S, Cantor $\mathrm{H}$. Regulatory T cells and autoimmune disease. Immunol Rev 2005; 204: 195-207.

103 Faria AMC, Weiner HL. Oral tolerance. Immunol Rev 2005; 206: 232-259.

104 Mueller DL. Mechanisms maintaining peripheral tolerance. Nat Immunol 2010; 11: 21-27.

105 Bilate AM, Lafaille JJ. Induced CD4 + Foxp3 + regulatory T cells in immune tolerance. Annu Rev Immunol 2012; 30: 733-758.

106 Canonica GW, Passalacqua G. Sublingual immunotherapy in the treatment of adult allergic rhinitis patients. Allergy 2006; 61(Suppl 81), 20-23.

107 Dahl R, Kapp A, Colombo G, de Monchy JG, Rak S, Emminger W et al. Efficacy and safety of sublingual immunotherapy with grass allergen tablets for seasonal allergic rhinoconjunctivitis. J Allergy Clin Immunol 2006: 118: 434-440.

108 Didier A, Malling HJ, Worm M, Horak F, Jäger S, Montagut A et al. Optimal dose, efficacy, and safety of once-daily sublingual immunotherapy with a 5-grass pollen tablet for seasonal allergic rhinitis. J Allergy Clin Immunol 2007; 120: 1338-1345.

109 Faria A, Weiner HL. Oral tolerance: therapeutical implications for autoimmune disease. Clin Dev Immunol 2006; 13: 143-157.

110 Skyler JS, Krischer JP, Wolfsdorf J, Cowie C, Palmer JP, Greenbaum C et al. Effects of oral insulin in relatives of patients with type 1 diabetes: the Diabetes Prevention Trial-Type 1. Diabetes Care 2005; 28 1068-1076.

111 Pascual DW, White MD, Larson T, Walters N. Impaired mucosal immunity in L-selectin-deficient mice orally immunized with a Salmonella vaccine vector. J Immunol 2001; 167: 407-415.

112 Jun S, Gilmore W, Callis G, Rynda A, Haddad A, Pascual DW. A live diarrheal vaccine imprints a Th2 cell bias and acts as an antiinflammatory vaccine. J Immunol 2005; 175: 6733-6740.

113 Sakaguchi S, Sakaguchi N, Asano M, Itoh M, Toda M. Immunologic selftolerance maintained by activated $\mathrm{T}$ cells expressing IL-2 receptor $\alpha$-chains (CD25): breakdown of a single mechanism of self-tolerance causes various autoimmune diseases. J Immunol 1995; 155: 1151-1164.

114 Hori S, Takahashi T, Sakaguchi S. Control of autoimmunity by naturally arising regulatory CD4 + T cells. Adv Immunol 2003; 81: 331-371.

115 Huber S, Schramm C, Lehr HA, Mann A, Schmitt S, Becker C et al. Cutting edge: TGF- $\beta$ signaling is required for the in vivo expansion and immunosuppressive capacity of regulatory $\mathrm{CD} 4+\mathrm{CD} 25+\mathrm{T}$ cells. J Immunol 2004; 173: 6526-6531. 
116 Morgan ME, Flierman R, van Duivenvoorde LM, Witteveen HJ, van Ewijk W, van Laar JM et al. Effective treatment of collagen-induced arthritis by adoptive transfer of CD25 + regulatory T cells. Arthritis Rheum 2005; 52: 2212-2221.

117 Hori S, Nomura T, Sakaguchi S. Control of regulatory T cell development by the transcription factor Foxp3. Science 2003; 99: 1057-1061.

118 Fontenot JD, Gavin MA, Rudensky AY. FoxP3 programs the development and function of CD4 + CD25 + regulatory T cells. Nat Immunol 2003; 4: 330-336.

119 Vieira PL, Christensen JR, Minaee S, O'Neill EJ, Barrat FJ, Boonstra A et al. IL-10-secreting regulatory $T$ cells do not express FoxP3 but have comparable regulatory function to naturally occurring $\mathrm{CD} 4+\mathrm{CD} 25+$ regulatory T cells. J Immunol 2004; 172: 5986-5993.

120 Chen W, Jin W, Hardegen N, Lei KJ, Li L, Marinos N et al. Conversion of peripheral $\mathrm{CD} 4+\mathrm{CD} 25$ - naive $\mathrm{T}$ cells into $\mathrm{CD} 4+\mathrm{CD} 25+$ regulatory T cells by TGF- $\beta$ induction of transcription factor FoxP3. J Exp Med 2003; 198: 1875-1886.

121 Oida T, Xu L, Weiner HL, Kitani A, Strober W. TGF- $\beta$-mediated suppression by $\mathrm{CD} 4+\mathrm{CD} 25+\mathrm{T}$ cells is facilitated by CTLA-4 signaling. J Immunol 2006; 177: 2331-2339.

122 Shimizu J. Stimulation of CD4 + CD25 + regulatory T cells through GITR breaks immunological self-tolerance. Nat Immunol 2002; 3: 135-142.

123 Faria AM, Maron R, Ficker SM, Slavin AJ, Spahn T, Weiner HL. Oral tolerance induced by continuous feeding: enhanced up-regulation of transforming growth factor- $\beta /$ interleukin-10 and suppression of experimental autoimmune encephalomyelitis. J Autoimmun 2003; 20: 135-145.

124 Zheng S, Wang J, Horwitz DA. Cutting edge: FoxP3 + CD4 + CD25+ regulatory T cells induced by IL-2 and TGF- $\beta$ are resistant to Th17 conversion by IL-6. J Immunol 2008; 180: 7112-7116.

125 Weiner HL. Oral tolerance: immune mechanisms and the generation of Th3-type TGF- $\beta$-secreting regulatory cells. Microbes Infect 2001; 3: 947-954.

126 Mowat AM. Anatomical basis of tolerance and immunity to intestinal antigens. Nat Rev Immunol 2003; 3: 331-341.

127 Wildbaum G, Netzer N, Karin N. Tr1-dependent active tolerance blunts the pathogenic effects of determinant spreading. J Clin Invest 2002; 110: 701-710.

128 Santos LM, al-Sabbagh A, Londono A, Weiner HL. Oral tolerance to myelin basic protein induces regulatory TGF- $\beta$-secreting T cells in Peyer's patches of SJL mice. Cell Immunol 1994; 157: 439-447.

129 Chen ML, Yan BS, Bando Y, Kuchroo VK, Weiner HL. Latency-associated peptide identifies a novel $C D 4+C D 25+$ regulatory $T$ cell subset with TGF- $\beta$-mediated function and enhances suppression of experimental autoimmune encephalomyelitis. J Immunol 2008; 180: 7327-7337.

130 Niedbala W, Wei XQ, Cai B, Hueber AJ, Leung BP, McInnes IB et al. IL-35 is a novel cytokine with therapeutic effects against collagen-induced arthritis through the expansion of regulatory T cells and suppression of Th17 cells. Eur J Immunol 2007; 37: 3021-3029.

131 Kochetkova I, Golden S, Holderness K, Callis G, Pascual DW. IL-35 stimulation of $\mathrm{CD} 39+$ regulatory $\mathrm{T}$ cells confers protection against collagen II-induced arthritis via the production of IL-10. J Immunol 2010; 184: 7144-7153.

132 Collison LW, Workman CJ, Kuo TT, Boyd K, Wang Y, Vignali KM et al. The inhibitory cytokine IL-35 contributes to regulatory T-cell function. Nature 2007; 450: 566-569.

133 Wirtz S, Billmeier U, Mchedlidze T, Blumberg RS, Neurath MF. Interleukin-35 mediates mucosal immune responses that protect against T-cell-dependent colitis. Gastroenterol 2011; 141: 1875-1886.

134 Collison LW, Chaturvedi V, Henderson AL, Giacomin PR, Guy C, Bankoti J et al. IL-35-mediated induction of a potent regulatory $\mathrm{T}$ cell population. Nat Immunol 2010; 11: 1093-1101.

135 Collison LW, Pillai MR, Chaturvedi V, Vignali DA. Regulatory T cell suppression is potentiated by target $\mathrm{T}$ cells in a cell contact, IL-35and IL-10-dependent manner. J Immunol 2009; 182: 6121-6128.

136 Kulkarni AB, Ward JM, Yaswen L, Mackall CL, Bauer SR, Huh CG et al. Transforming growth factor- $\beta 1$ null mice: an animal model for inflammatory disorders. Am J Pathol 1995; 146: 264-275.

137 Jun S, Ochoa-Repáraz J, Zlotkowska D, Hoyt T, Pascual DW. Bystandermediated stimulation of proteolipid protein-specific regulatory $T$ (Treg) cells confers protection against experimental autoimmune encephalomyelitis (EAE) via TGF-B. J Neuroimmunol 2012; 245: 39-47.

138 Ochoa-Repáraz J, Rynda A, Ascón MA, Yang X, Kochetkova I, Riccardi C et al. IL-13 production by regulatory $\mathrm{T}$ cells protects against experimental autoimmune encephalomyelitis independently of autoantigen. J Immunol 2008; 181: 954-968.

139 Carmona L, Cross M, Williams B, Lassere M, March L. Rheumatoid arthritis. Best Pract Res Clin Rheumatol 2010; 24: 733-745.

140 Scott DL, Wolfe F, Huizinga TW. Rheumatoid arthritis. Lancet 2012; 376: 1094-1108.

141 Feldmann M, Brennan FM, Maini RN. Role of cytokines in rheumatoid arthritis. Annu Rev Immunol 1996; 14: 397-440.

142 Brennan FM, Maini RN, Feldmann M. Role of pro-inflammatory cytokines in rheumatoid arthritis. Springer Semin Immunopathol 1998; 20: 133-147.

143 Kannan K, Ortmann RA, Kimpel D. Animal models of rheumatoid arthritis and their relevance to human disease. Pathophysiology 2005; 12: 167-181.

144 Di Giovine FS, Nuki G, Duff GW. Tumor necrosis factor in synovial exudates. Ann Rheum Dis 1988; 47: 768-772.

145 Saxne T, Palladino MA Jr, Heinegard D, Talal N, Wollheim FA. Detection of tumor necrosis factor alpha but not tumor necrosis factor beta in rheumatoid arthritis synovial fluid and serum. Arithitis Rheum 1988; 31: 1041-1045.

146 Firestein GS, Alvaro-Gracia JM, Maki R. Quantitative analysis of cytokine gene expression in rheumatoid arthritis. J Immunol 1990; 144: 3347-3353.

147 Piguet PF, Grau GE, Vesin C, Loetscher H, Gentz R, Lesslauer W. Evolution of collagen arthritis in mice is arrested by treatment with anti-tumour necrosis factor (TNF) antibody or a recombinant soluble TNF receptor. Immunol 1992; 77: 510-514.

148 Thorbecke GJ, Shah R, Leu CH, Kuruvilla AP, Hardison AM, Palladino MA. Involvement of endogenous tumor necrosis factor $\alpha$ and transforming growth factor $\beta$ during induction of collagen type II arthritis in mice. Proc Natl Acad Sci USA 1992; 89: 7375-7379.

149 Williams RO, Feldmann M, Maini RN. Anti-tumor necrosis factor ameliorates joint disease in murine collagen-induced arthritis. Proc Natl Acad Sci USA 1992; 89: 9784-9788.

150 Moreland LW, Baumgartner SW, Schiff MH, Tindall EA, Fleischmann RM, Weaver AL et al. Treatment of rheumatoid arthritis with a recombinant human tumor necrosis factor receptor (p75)-Fc fusion protein. N Engl J Med 1997; 337: 141-147.

151 Lipsky PE, van der Heijde DM, St. Clair EW, Furst DE, Breedveld FC, Kalden JR et al. Infliximab and methotrexate in the treatment of rheumatoid arthritis. Anti-Tumor Necrosis Factor Trial in Rheumatoid Arthritis with Concomitant Therapy Study Group. N Engl J Med 2000; 343: 1594-1602.

152 Fava RA, Olsen NJ, Postlethwaite AE, Broadley KN, Davidson JM, Nanney LB et al. Transforming growth factor beta 1 (TGF- $\beta 1$ ) induced neutrophil recruitment to synovial tissues: implications for TGF- $\beta$-driven synovial inflammation and hyperplasia. J Exp Med 1991; 173: $1121-1132$

153 Cassatella MA, Gasperini S, Russo MP. Cytokine expression and release by neutrophils. Ann NY Acad Sci 1997; 832: 233-242.

154 Manoury-Schwartz B, Chiocchia G, Bessis N, Abehsira-Amar O, Batteux F, Muller S et al. High susceptibility to collagen-induced arthritis in mice lacking IFN- $\gamma$ receptors. J Immunol 1997; 158: 5501-5506.

155 Vermeire K, Heremans H, Vandeputte M, Huang S, Billiau A, Matthys P. Accelerated collagen-induced arthritis in IFN- $\gamma$ receptor-deficient mice. J Immunol 1997; 58: 550713.

156 Kelchtermans H, De Klerck B, Mitera T, Van Balen M, Bullens D, Billiau $A$ et al. Defective CD4 $+C D 25+$ regulatory $T$ cell functioning in collagen-induced arthritis: an important factor in pathogenesis, counter-regulated by endogenous IFN- $\gamma$. Arthritis Res Ther 2005; 7: R402-R415.

157 Finnegan A, Kaplan CD, Cao Y, Eibel H, Glant TT, Zhang J. Collageninduced arthritis is exacerbated in IL-10-deficient mice. Arthritis Res Ther 2003; 5: R18-R24.

158 Weaver CT, Harrington LE, Mangan PR, Gavrieli M, Murphy KM. Th17: an effector CD4 T cell lineage with regulatory T cell ties. Immunity 2006; 24: 677-688.

159 Ley K, Smith E, Stark MA. IL-17A-producing neutrophil-regulatory Tn lymphocytes. Immunol Res 2006; 34: 229-242.

160 Nurieva RI, Treuting P, Duong J, Flavell RA, Dong C. Inducible costimulator is essential for collagen-induced arthritis. J Clin Invest 2003; 111: 701-706

161 Chabaud M, Durand JM, Buchs N, Fossiez F, Page G, Frappart L et al. Human interleukin-17: a $T$ cell-derived proinflammatory cytokine 
produced by the rheumatoid synovium. Arthritis Rheum 1999; 42: 963-970.

162 Ziolkowska M, Koc A, Luszczykiewicz G, Ksiezopolska-Pietrzak K, Klimczak E, Chwalinska-Sadowska $\mathrm{H}$ et al. High levels of IL-17 in rheumatoid arthritis patients: IL-15 triggers in vitro IL-17 production via cyclosporin A-sensitive mechanism. J Immunol 2000; 164: 2832-2838.

$163 \mathrm{Kim}$ HR, Cho ML, Kim KW, Juhn JY, Hwang SY, Yoon CH et al. Upregulation of IL-23p19 expression in rheumatoid arthritis synovial fibroblasts by IL-17 through PI3-kinase-, NF-kB- and p38 MAPKdependent signalling pathways. Rheumatol 2007; 46: 57-64.

164 Lubberts E, Koenders MI, OppersWalgreen B, van den Bersselaar L, Coenen-Roo CJJ, Joosten LA et al. Treatment with a neutralizing antimurine interleukin-17 antibody after the onset of collagen-induced arthritis reduces joint inflammation, cartilage destruction, and bone erosion. Arthritis Rheum 2004; 50: 650-659.

165 Courtenay JS, Dallman MJ, Dayan AD, Martin A, Mosedale B. Immunization against heterologous type II collagen induces arthritis in mice. Nature 1980; 283: 666-668.

166 Kochetkova I, Trunkle T, Callis G, Pascual DW. Vaccination without autoantigen protects against collagen II-induced arthritis via immune deviation and regulatory T cells. J Immunol 2008; 181: 2741-2752.

167 Fletcher JM, Lonergan R, Costelloe L, Kinsella K, Moran B, O'Farrelly C et al. CD39 + Foxp3 + regulatory T Cells suppress pathogenic Th17 cells and are impaired in multiple sclerosis. J Immunol 2009; 183: 7602-7610.

168 Borsellino G, Kleinewietfeld M, Mitri DD, Sternjak A, Diamantini A, Giometto $\mathrm{R}$ et al. Expression of ectonucleotidase CD39 by Foxp3 + Treg cells: hydrolysis of extracellular ATP and immune suppression. Blood 2007; 110: 1225-1232.

169 Bynoe MS, Viret C. Foxp3 + CD4 + T cell-mediated immunosuppression involves extracellular nucleotide catabolism. Trends Immunol 2008; 29: 99-102.

170 Kochetkova I, Thornburg T, Callis G, Pascual DW. Segregated regulatory CD39+CD4 + T cell function: TGF- 3 -producing Foxp3- and IL-10producing Foxp $3+$ cells are interdependent for protection against collagen-induced arthritis. J Immunol 2011; 187: 4654-4666.

171 Lehmann D, Ben-Nun A. Bacterial agents protect against autoimmune disease. I. Mice pre-exposed to Bordetella pertussis or Mycobacterium tuberculosis are highly refractory to induction of experimental autoimmune encephalomyelitis. J Autoimmun 1992; 5: 675-690.

172 Lee J, Reinke EK, Zozulya AL, Sandor M, Fabry Z. Mycobacterium bovis bacille Calmette-Guérin infection in the CNS suppresses experimental autoimmune encephalomyelitis and Th17 responses in an IFN- $\gamma$-independent manner. J Immunol 2008; 181: 6201-6212.

173 Marshall E. Drug trials. Violent reaction to monoclonal antibody therapy remains a mystery. Science 2006; 311: 1688-1689.

(c) (i) () $\odot$ This work is licensed under a Creative Commons Attribution-NonCommercial-NoDerivs 3.0 Unported License. To view a copy of this license, visit http:// creativecommons.org/licenses/by-nc-nd/3.0/ 